\title{
A METHOD OF EMULATING THE PLAUSIBLE VISUAL OF MALAYSIAN SHADOW PLAY WITH COMPUTER-GENERATED IMAGERY (CGI)
}

\author{
Kheng-Kia Khor \\ khorkk@utar.edu.my \\ Department of Advertising, Faculty of Arts and Social Science, \\ Universiti Tunku Abdul Rahman, 31900 Perak, Malaysia.
}

\begin{abstract}
Wayang kulit Kelantan, a preeminent shadow play in Malaysia is threatened with imminent extinction. At this moment, the efforts made to preserve this traditional cultural heritage are insufficient. Therefore it is clear that with the current situation in Malaysia and the level of official support, Wayang kulit Kelantan is unlikely to last long. With regard to this issue, on one hand, some researchers suggest to digitise wayang kulit Kelantan as a mean of preservation. On the other hand, there are also researchers who attest that there is a dire need for Malaysians to promote this art form by using modern technology.
\end{abstract}

This paper presents a methodology framework of using Computer Generated Imagery (CGI) to emulate the visual of wayang kulit Kelantan. Experiments have been carried out to vindicate the veracity of the framework, and the results show that realistic and plausible visual of wayang kulit Kelantan can be emulated by using the proposed framework.

Keywords: Digital Puppetry, wayang kulit Kelantan, Malaysian shadow play.

\section{Introduction}

In the attempt to preserve and safeguard the unique traditional wayang kulit (shadow play), the United Nations Educational, Scientific and Cultural Organization (UNESCO) has designated Indonesian wayang kulit purwa as a Masterpiece of Oral and Intangible Heritage of Humanity on 7th November 2003. The term wayang kulit combines two important words: "wayang", which can be translated as shadow, and "kulit", which means leather. Thus wayang kulit indicates a form of shadow theatre performed with leather puppets [1].

Today, the preservation of Indonesian wayang kulit purwa has been executed in a very promising way but Malaysian wayang kulit Kelantan is threatened with imminent extinction [2]. This dying art form was one time fairly widespread and extremely popular in the state of Kelantan in Malaysia. In the 1960s, there were more than 300 puppeteers in Kelantan but now there are less than six [3].

Existing evidences indicate the origin of wayang kulit Kelantan to a proto-Javanese wayang kulit. However, through substantial adaptation and localisation, wayang kulit 
Kelantan has developed its idiosyncratic characteristics and styles [4]. Although both Indonesian wayang kulit purwa and Malaysian wayang kulit Kelantan use the same source of repertoire (Ramayana) with the same principal characters (with slight differences in spelling); there are distinctively different in terms of their shadow colours, distortions and light source [5].

Wayang kulit Kelantan shows greater level of shadow distortion compared to wayang kulit purwa due to the differences in the size of kelir (screen), distances and positions of light source. Moreover, the puppets of wayang kulit Kelantan cast colourful shadows on the screen whereas the puppets of wayang kulit purwa are opaque and only cast black shadows. Fig. 1 depicts the visual of wayang kulit Kelantan during a performance.

Fig 1: The visual of Wayang Kulit Kelantan.

With the advent of modern entertainment technology and media such as television, cinema and Internet, wayang kulit Kelantan is facing the predicament of extinction. In order to survive in the era of digitalisation and globalisation, it needs a new alternative media output, to be digitalised into cyber world and to be watched on the computer screen or cinema. Tan, Abdullah and Osman from Universiti Sains Malaysia (USM) pointed out that there is a need for Malaysians to promote and provide greater accessibility to the dying art form by using modern technology such as digital media [6]. Che. Mohd. Nasir Yussof, a professional puppeteer who helms the wayang kulit Kelantan groups in National Arts Academy (ASWARA) affirmed that the digitalisation of Wayang Kulit Kelantan will be very helpful in delivering information and promoting this art form through internet or online social media [7]. Kaplin believes this digital form of puppetry will not mean the "death of traditional [form of] puppetry, but will probably lead them to be "preserved for their historic, spiritual or folkloric value, like endangered species on a game preserve. Digital puppetry is a revolutionary idea, for it expands the realm of puppetry beyond all definitions that center upon the materiality of the puppets [8].

\section{Related Works}

In 2009, a group of Indonesians has formed and created several web sites to promote "ewayang." It is a type of virtual shadow play in which all puppets were created digitally and were staged and performed exclusively in digital environment. An adept in the department of shadow play in Institut Seni Indonesia (ISI), Bambang Murtiyoso asserts that there is a need for the Indonesians to adapt and triumph over the influence of Western technology towards their local cultural identity. He urges the local talents to intertwine their local cultural with foreign technology in order to generate a "truly new" culture. He further praises on the "ewayang" as a quintessence of his proposition [9].

There are also Malaysian researchers who combine the modern technology with the art of shadow play. For example, in 1996, under a short-term grant awarded by Universiti Malaysia Sarawak (UNIMAS), a research project known as "Wayang Virtual" was established as an experimental version of the traditional shadow play. The virtual version of the traditional shadow puppets were combined with a 3D animated figure and controlled by a puppeteer using a computer mouse while the visuals were juxtaposed and projected on a white screen [10]. 
In 2011, Dahlan Abdul Ghani from Universiti Kuala Lumpur (UniKL) has developed a prototype design on wayang kulit in computer-generated environment. However, the result from his survey shows that the Malaysians prefer wayang kulit in traditional manner compared to his computer-generated puppet. The reason is may be because the virtual puppet created by him lacks the visual aesthetics of wayang kulit Kelantan even though his aim was to preserve this traditional shadow puppet play [11].

In 2012, a group of researchers in Universiti Utara Malaysia (UUM) has invented a prototype of an interactive digital puppetry called e-WayCool to help students to learn mathematics in Malaysian Primary School Standard Curriculum. One of the objectives of this research is to preserve the wayang kulit Kelantan. However, the virtual puppet used in eWayCool apparently belongs to Indonesian wayang kulit purwa rather than Malaysian wayang kulit Kelantan [12].

With regard to the preservation of Malaysian wayang kulit by using digital media and technology, most of the efforts paid no heed to its original visual aesthetics. Most of them have depicted the visual of Indonesian wayang kulit which is very much different compared to the wayang kulit Kelantan. Therefore, this paper presents the use of Computer-Generated Imagery (CGI) to emulate the identical visual of wayang kulit Kelantan.

\section{Methodology Framework}

Computer-generated imagery (CGI) is the application of the field of computer graphics or, more specifically, 3-dimensional computer graphics to create special effects in animations, video games, films, television programs, commercials, simulation and printed media.

The objective of this paper is to propose a methodology framework to emulate the plausible visual of wayang kulit Kelantan. In the experiment, there are three important elements to be considered; (i) puppet design, (ii) screen and (iii) light source. Similarly to an actual wayang kulit Kelantan performance, these elements must be ready prior to the show. Moreover, an experienced puppeteer is needed to animate the puppets. For the experiment, first, we have to create the virtual puppet(s), a virtual screen and a virtual light source. Upon the completion of these elements, a computer animator has to animate these elements in ways like an actual puppeteer, by using computer input devices such as a mouse.

Fig 2: The methodology framework of the experiment.

As shown in Fig. 2, the task of simulating the visual of wayang kulit Kelantan can be divided into four phases. The first phase involves the creation of virtual puppet(s), a virtual light source and a virtual screen. The tangible puppets have to be photographed, digitalized and "cleaned" before being transferred (or mapped) onto virtual objects with identical shapes and sizes. Animating these newly created virtual objects (puppets, light source and screen) is the following phase. The third phase is to create a virtual camera to capture the screen's movement/ vibration effect, puppets' movement and light source's movement/ flickering effect. The final phrase involves exportation of these visual elements. In the following section the author presents the detailed processes and methodologies in these phases.. 


\section{Experiment}

Two wayang kulit Kelantan puppets have been chosen to carry out the experiment; they are Pohon Beringin and Wak Long.

Fig 3: The main puppets of wayang kulit Kelatan; from left: Pohon Beringin \& Wak Long

The Pohon Beringin is a highly elegant tree or leaf-shaped puppet shown during the opening and closing of all wayang kulit Kelantan performances. It is unanimously perceived as the most important puppet among all. There are two types of Pohon Beringin in wayang kulit Kelantan; the first type is filled with the arabesques design of vegetal patterns on its entire surface (Fig 3). The second type is designed and crated with the motifs from natural environments such as birds, fish, crocodiles, elephants, monkeys, snakes, tree, branches, flowers, etc. on a shape of a large leaf, tree or mountain. Both sides of the Pohon Beringin are a mirror image of the other. [13].

The Pohon Beringin puppet comes in one piece with the height of approximately $75 \mathrm{~cm}$ and there is no extra joint or parts within. In wayang kulit Kelantan performances, the Pohon Beringin puppet represents the World Tree or Cosmic Mountain which is linking the earth and sky. It also symbolises the cosmos, with different levels of creation manifested in it. It encapsulates the essence of all things in the performances, reflecting all phenomena and objects in the natural world. In the performances of wayang kulit Kelantan, the shape of the puppet was distorted when the puppeteer presses it towards the screen, move or shake it swiftly.

Wak Long is one of the main clown characters in wayang kulit Kelantan performances, which is also an important comic characters not derived from the Hindu Ramayana epic [14]. The Wak Long puppet is always painted red and displays a comical characteristic with his broad, bulbous nose, round eye, pot-belly, large backside and sarong-clad torsos. Among all the wayang kulit Kelantan puppets, Wak Long puppet contains the most sophisticate joints including two movable articulated arms, movable mouth and eyebrow.

The photographs of both puppets were digitised, retouched and cleaned up by using computer graphic software. For the Wak Long puppet, the different joints and movable parts such as jaw and limbs need to be separated into different layers. In addition to it, the opacity map (grey-scale) files were also been created to specify areas of opacity and transparency of the puppets. The pure white areas of the opacity map will allow the corresponding areas of the puppets to be totally visible, while pure black areas cause the corresponding areas of the puppets to be completely transparent. The level of transparency in the materials is controlled and determined by the level of darkness in the opacity map.

Both puppets were modeled in 3D computer graphic application (in this case the author use Autodesk 3D Studio Max 2016). The digital photos of both puppets were mapped into the virtual puppets accordingly with their opacity files.

Lastly in the modeling stage, a virtual screen was created with its identical setting in the real world $(250 \mathrm{~cm}$ width $\mathrm{x} 180 \mathrm{~cm}$ height with 77 degree titling forward).

The traditional Wayang Kulit Kelantan uses paraffin oil lamp as its light source. The dramatic flickering of the lamp sets the mystical atmosphere over the performance. The shimmering soft light of the lamp casts a mysterious atmosphere over the performance area, and because of the flickering, the puppets were seen from the shadow side often appears as if they were alive and breathing. In the recent years the use of the electric light bulb for this 
purpose often resulted in a loss of this natural quality. In order to simulate the visual of the modern wayang kulit Kelantan performance, a virtual light bulb was added in the virtual setting. It was animated to create the swinging effect just like how a puppeteer moves the hanging light bulb during the actual performances (Fig 4).

Fig 4: The setting of virtual Wayang Kulit Kelantan.

Apart from the virtual light bulb, the author also replaced it with the flickering fire effects in another experiment, to emulate the fire effects of a paraffin oil lamp. The intensity of the virtual light source was animated and artificial flickering flame effect has been created and superimposed digitally onto the final visual (Fig 5).

Fig 5: The computer-generated fire effects as the light source.

Next, a series of dummy objects were created in order to control the different parts of the Pohon Beringin puppet. These dummy objects are invisible on rendering/ output and were linked with proper hierarchy in order to control the distortion of specific parts of the puppet (Fig. 6).

Fig 6: The virtual Pohon Beringin with attached dummy objects.

The Pohon Beringin puppet was animated with computer-generated tweening technique to perform an arc movement from right to left and touches the centre of the screen during the half-way of the movement. The term tweening in CGI software means the animator creates the keyframes (important frames of a sequence), such as the starting and ending position of the Pohon Beringin puppet, then the computer software will smoothly translate the object from the starting point to the ending point. The animator can amend the movement at any point, shifting keyframes back and forth to improve the timing and dynamics of a movement, or insert additional keyframes into the 'in between' to further refine and improve the movement.

When the Pohon Beringin puppet touches the screen, the top part of the puppet was distorted and this effect was achieved by moving and rotating the dummy object on the top part of the puppet. Throughout the arc movement of the puppet, different parts of it have been distorted by manipulating the relevant dummy objects.

Generally the computer-generated shadow has two important parameters to control the transparency of shadow and the softness of its edges. The area shadow function creates a soft edge that becomes more noticeable as the distance between the object and the shadow increases. The softness of the shadow's edges was determined by the sizes of area shadow. The bigger size of the area shadow will make the softness of the shadow's edge become more distinctive (Fig 7).

Fig 7: Area Shadow size determines the softness of the edge of the shadow.

Both of the parameters have been activated and adjusted in this experiment. In addition to it, the cast colourful shadows function in the materials of the puppets also need to be activated.

The Wak Long puppet consists of two moveable articulated arms. The puppeteer controls and moves the arms of the puppet by manipulating the sticks connected to the end of each 
articulated arm. Each arm of the Wak Long puppet consists of two movable parts. In virtual wayang kulit Kelantan environment, all of these moveable parts were modeled and texturemapped using the methods discussed earlier. They were later been arranged, positioned and linked with proper axis points and hierarchy. These parts were later being rotated and animated to mimic the movements of the Wak Long puppet in an actual performance (Fig 8).

Fig 8: The movements of the virtual Wak Long puppet.

The movements of eyebrow and mouth of a tangible Wak Long puppet were controlled by a string. The moveable eyebrow of Wak Long puppet is actually a bent bamboo attached to a string. By pulling the string downward and releasing it to its original position, the puppet's eyebrow and mouth will move simultaneously.

Fig 9: The Movements of the mouths, eyebrow and string of Virtual Wak Long Puppet.

To achieve the above mentioned visual, a virtual bent thin cylinder was modeled to operate as the eye brow of the puppet with a virtual string attached to it. The elasticity of the stick was manipulated and animated synchronously with the movement of its mouth and string; creating the visual of moveable mouth, eyebrow and string (Fig 9).

\section{Results and Analysis}

The results of the experiments have shown plausible and convincing visual of wayang kulit Kelantan. The differences between the visual of computer-generated wayang kulit Kelantan with the actual one are indistinguishable (or very subtle). This computer-generated visual comprised of distinctive shadow's colours, distortions, softness of edges, generated abreast with the movements of the virtual puppets and light source.

In addition to the capabilities of visual simulation, from the experiment results, all computer-generated visual elements (i.e. the colour and intensity of light source, the softness of the edges of shadows and the transparency of the screen) are adjustable and can be animated. It is very difficult (or maybe impossible) for the puppeteers to control these elements in any actual performances.

The fly in the ointment of these experiments is that all the animations were done not in "real time". "Real-time" in shadow play refers to a synchronicity between the puppeteer's control and the puppet's resultant movement [15]. Even though the animation process in virtual wayang kulit Kelantan eliminates the human errors, it also disconnects the interaction between the puppeteer (in this case, animator) and the audience.

\section{Conclusion}

The objective of this paper is to propose a methodology framework of using CGI to emulate the visual of wayang kulit Kelantan. The results of the experiments have shown high 
level of verisimilitude in terms of the quality of puppets' movements, colours of shadows (translucency of puppets), movements of light source, distortions of puppets, softness of the edges of shadows, movements of eyebrow, mouth and string which was attached to the puppets. The author hopes the experiment results will boost more creation and adaptation of wayang kulit Kelantan's visual in movies, animations, video games and films. It is also hoped that with the advent of computer technology, the simulation of virtual wayang kulit Kelantan will become more user-friendly and accessible. Last but not least, the author hopes to see more efforts in the creation of virtual wayang kulit Kelantan as both of them share the similarities in their visuals on screen and the author believes they can co-exist and benefit each other.

The work presented here has focused on the emulation of the visual of wayang kulit Kelantan, with the use of CGI. On one hand, the work by Ghani [11] considers only on 3D puppet modeling without paying heed to screen and light source. On the other hand, the work by Tan et al. [6] takes a different approach based on the visual simulation and interactive animation of a Javanese shadow play puppet by using OpenGL technique. While the present study is related to the diminishing wayang kulit Kelantan, it has successfully emulated the plausible visual of the art form, which was not considered (or lacking) in other earlier researches.

\section{References}

[1] Van Ness, C. E., \& Prawirohardjo, S.: Javanese Wayang Kulit. Oxford University Press, Malaysia (1980)

[2] Yousof, G. S.: The Encyclopedia of Malaysia: Performing Arts. Archipelago Press, Singapore (2004)

[3] Sweeney, A.: The Ramayana and The Malay Shadow-Play. Penerbit Universiti Kebangsaan Malaysia, Malaysia (1972)

[4] Osnes, M. B.: The Shadow Puppet Theatre of Malaysia- A Study of Wayang Kulit with Performance Scripts and Puppet Design. McFarland \& Company Inc, US (2010)

[5] Khor, K.K. \& Yuen, M.C.: A Study on the Visual Styles of Wayang Kulit Kelantan and Its Capturing Methods. $6^{\text {th }}$ International Conference on Computer Graphics, Imaging and Visualization. pp.423-428 (2009)

[6] Tan, K.L., Talib, A. Z. \& Osman, M. A.: Real-Time Visual Simulation and Interactive Animation of Shadow Play Puppets Using OpenGL. Proceedings of World Academy Of Science, Engineering And Technology, Volume 35 (2008)

[7] Lugiman, F. A.: Performing Art Traditional Heritage: Implementation of Website to Convey Information of Wayang Kulit. Universiti Teknologi MARA, Malaysia (2006)

[8] Kaplin, S.: Puppetry into the next millennium. Pupptry International, 1, pp. 37- 39 (1994)

[9] Murtiyoso, B.: Prospek Seni Budaya Indonesia Dalam Menghadapi Era Persaingan Iptek \& Era Global. Retrieved January 11, 2016, from https://www.facebook.com/notes/wayang-nusantara-indonesian-shadow-puppets/prospek-senibudaya-indonesia-dalam-menghadapi-era-persaingan-iptek-era-global/226107636109/ (2009)

[10] Abdul Wahid, H.: The Integration and an Experiment of a Traditional Wayang Kulit Performance and Electroacoustic Music. The Languange of Electroacoustic Music, pp. 1-7 (2007)

[11] Abdul Ghani, D.: Wayang Kulit: Digital Puppetry Character Rigging Using Maya MEL Language. $4^{\text {th }}$ International Conference on Modeling, Simulation and Applied Optimization (ICMSAO), pp. 1-4 (2011)

[12] Jasni, A., Zulikha, J. \& Mohd-Amran, M. A.: eWayCool: Utilizing the Digital Wayang Kulit for Mathematic Learning. AWER Procedia Information Technology \& Computer Science (2012) 
[13] Kingham, S.: The Kayon In The Shadow Play of Kelantan And Bali. In Faridah Noor Mohd Noor (Editor). Dimensions of the Shadow Play in Malay Civilisation. Centre for Civilisational Dialogue, University of Malaya, Malaysia (2006)

[14] Matusky, P.: Malaysian Shadow Play and Music- Continuity of an Oral Tradition. The Asian Centre, Malaysia (1997)

[15] Tillis, S.: The Art of Puppetry in the Age of Media Production. Puppets, Mask, and Performing Objects. University and Massachusetts Institute of Technology. Pp. 173- 185 (2001) 